\title{
A New Woman in an Old World: Discovering the Traumatic Psyche of Blanche DuBois in the play A Streetcar Named Desire
}

\author{
Tamanna Farahdina \\ Department of EnglishDaffodil International University
}

\begin{abstract}
The present paper examines the concept of the new women of the twentieth century American society through the character of Blanche DuBois from Tennessee Williams' play 'A Streetcar Named Desire'. It also analyzes the reasons behind Blanche's mental breakdown at the end of the play based on Clara Thompson's psychoanalytic theories of personality development. According to Thompson, women's psychology is actually formed by the passive acceptance of social norms related to cultural and economic factors. But the defiance of these norms becomes a threat to the traditional patriarchal society and throws women to an imbalance competition with men which may cause a troubled psyche. Blanche DuBois embodies the spirit of the new women seeking freedom and privilege like the male members of the society and, when this emotional state is constantly undermined and suppressed by the old or conventional culture, it eventually brings forth her psychological collapse.
\end{abstract}

Keywords: Cultural Factor, Economic Factor, New Women, Patriarchy, Women's Psychology

A woman's personality is built up in a different manner than a man's on the most basic point. Images of what we typically consider masculine and feminine in appearance and behavior is a result of our cultural set up. Society shapes women's thought in such a manner that they cannot think of surviving without the help of anyone, before marriage, they are dependent on parents and after marriage this responsibility belongs to her husband. And this idea is installed in women from early childhood so that they can accept these stereotypes without any question and, consequently displays and upholds patriarchal norms and beliefs. Tennessee Williams, in most of his plays, exemplifies these types of typical, vulnerable and helpless women in American society. But in the play A Streetcar Named Desire, he creates a female character, Blanche Dubois, who is totally dissimilar from other female characters of Williams' plays. The uniqueness of Blanche echoes the spirit of the 'New Women', a term that was generally used to bring up to an economically independent woman in the late nineteenth century who wanted social, political, and educational equality among men. Through Blanche, Williams emphasizes the value of individuality and freedom of choice and also shows what can happen when the new and old world values collide. The objective of this paper is to focus on the character of Blanche Dubois from a psychoanalytic point of view using American psychoanalyst Clara Thompson's theory of the psychology of women, where she describes the importance of cultural influences in personality development, to analyze the actions and words of Blanche and investigate the reasons behind her final destruction. The word 'new women' was introduced by the writer Sarah Grand, an Irish feminist writer, in her article "The New Aspect of the Woman Question," published in the North American Review in March 1894. The reasons behind the emergence of New Women were the ninetieth-century suffrage movement through which women got voting right and achieved freedom in a diversity of societal arenas, and also created a controversy and threat in both England and the United States. Moreover, the progress in urbanization and industrialization in the western states at that time also increased the educational and workplace opportunity for adult females. At the end of the nineteenth century, New Woman principles started to play an important part in complex social transforms that led to redefining gender roles, consolidating women's rights, and conquering male dominance. These women, possessing self-dependency and education, actually sought for an intellectual freedom to find themselves and their true identity which was not permissible even in the twentieth century modern world. Therefore, they were to face an overpowering situation which Sarah Grand brilliantly summarized in the following lines;

"Women were awaking from their long apathy, and, as they awoke, like healthy hungry children unable to articulate, they began to whimper for they knew not what. They might have been easily satisfied at that time had not society, like an ill-conditioned and ignorant nurse, ..............shaken them and beaten them and stormed at them until what was once a little wail became convulsive shrieks and roused up the whole human household. Then man, disturbed by 
the uproar, came upstairs all anger and irritation,..............added his own old theories to the din, but, finding they did not act rapidly, formed new ones, and made an intolerable nuisance of himself with his opinions and advice."

(Sarah Grand, 271)

Similarly, psychoanalyst Clara Thompson says that this change in women's personality has also a danger for women, which throws them in an uneven competition with men. This incongruent race remains dominant in almost every aspect of men and women life, such as social, cultural, economic and sexual, etc. Thomson, in her article 'Cultural Pressures in the Psychology of Women', presented a view of the position of women in twentieth centuryUnited States and identified various ways of the development of women' psychology in the light of cultural elements. She elucidates the point that the personality of any women, whether she is a traditional one or new women, is developed by the cultural and social factors which are formed by the so called 'superior' male members of the society. About new women, she says that though recently women have found opportunities of education, business, and some other outdoor activities, but "this is essentially a patriarchal culture and although many values are changing and these changes in the whole are working to the advantage of women, the patriarchal situation still presents limitations to a woman's free development of her interests. Also, the newer situations have their hazards in that they usually throw women into unequal competition with men. By unequal, the reference is not to biologic inequality, but an inequality resulting from prejudice and the greater advantages offered the male" (Thompson, 233). She thinks that this sort of situation creates 'masculinity complex' in the personality of women. They, having this masculinity complex, desires all the exclusive rights granted to men.In the play A Streetcar Named Desire, Blanche is depicted as a New Woman having this 'masculinity complex'. She is one of such females born and brought up in a rich family in the Old South. Because of being wealthy, she has the prospect to take proper education and, therefore, develops a refined and sensitive nature than other unprivileged women of that time. Her personality is shaped in a different way that she becomes responsive, intellectual and freedom seeker. Therefore, a 'masculinity complex' grows within her mind from her very childhood. In every matter of life, such as social, economic and sexual, she wants a complete freedom to control them as her own way. But the society has already set up some standards and norms by its male members that will never allow Blanche to go beyond it. Consequently, Blanche's 'masculinity complex' and social and cultural customs of patriarchal society constantly collide. The core reason of this collision, according to Thompson, lies in the economic structure of the society. The financial dependence on men deprives women of the privilege to control their own lives and the power to stand against men. Women's independent economic status is the material foundation to attain personal freedom. If women are dependent on men economically, they are deprived of all the equal rights. Hence, "intellectual freedom, the "power to think for oneself,' depends on financial freedom" (Woolf, 106). In the nineteenth century America, men at the center of the society control money, power and even women. They organized their own criteria to evaluate the society and other masses. Women of that time developed their personality in a way that they had to think it very natural to be dependent on both men, economically and mentally. Women had to keep beautiful appearance, behave graciously and flirt with men in order to delight them. So, it was inevitable that women would lose their self when faced with traditional customs and strict standards set by men.Blanche comes from Southern part of America and its economic structure is depended on a plantation that keeps women away from productive labor, so that they don't get the independent economic status. Though Blanche works outside because of economic necessity, she has to take to be a teacher in a high school which is reckoned as a decent occupation of women. But the confidence of Blanche as an independent woman cannot last longer since a teacher's income is not sufficient for her to endure the spirit of the high-born lady that she has lived in Belle Reve. So, she keeps dating with different men in Laurel. She doesn't have any other alternatives, because she is alone and economically helpless as well. She cannot accept this economic crisis, which becomes an obstacle against her accustomed life. A woman like Blanche, who is brought up in love and luxury, naturally cannot bear her inferior status. Thompson says "woman's lack of opportunity and economic dependence on men can lead to early rigidity narrowed outlook on life, as can any situation which curbs spontaneous development in either sex" (Thompson, 238). This is precisely what happens to Blanche, she cannot think about far reaching consequences of her act. She chooses an immoral way and keeps dating with a lot of men. Inculcating the spirit of the new women, she does not consider this immoral since it serves two purposes for her at the same time. In one hand, she finds a financial support and, on the other hand, she discovers an imaginary world to get away from the harsh reality.

But, this 'so called' immoral sexual act of Blanche also serves as one of the primary ingredients that lead to her tragedy. The patriarchal society sees women as a sex object or mere possessions of men. Blanche should not dare to enjoy freedom in sexual activity because "The cultural attitude about the sexual life of women has been one of denial. Passivity and masochism are usually considered essential characteristics of a woman's sexual drive" (Thompson, 235). So, the portrayed immorality of Blanche in Laurel does not match with the account of 
purity defining a stereotypical woman. This course of having affairs with other men is not acceptable to the patriarchal world as it sets out to undercut the traditional ideal lady and her domestic role. Eventually, Blanche is fired from her teacher position and also banished from the town. In consequence, Blanche loses her reputation in her hometown Laurel along with her financial means. Blanche doesn't have anything left except a black past and 'a trunk' that just carries her clothes and some worthless papers, then she has no choice but to seek refuge in the house of Stanley Kowalski, brother-in-law of Blanche, in New Orleans. Thus, Blanche becomes economically vulnerable to Stanley here.In New Orleans, Blanche stumbles on a more terrible situation; "Her expression is one of shocked disbelief. Her appearance is Incongruous to this setting" (Williams, 15) which Williams writes intentionally to show Blanche's uniqueness among others. This world is the world of Stanley Kowalski, a perfect illustration of male dominated society, who takes delight in his maleness. Williams examines the contrast and the conflict between the new women and the old world symbolically through the conflict between Blanche and Stanley. Stanley proclaims in the play,

"Every Man is a King!' and I am the king around here" (Williams, 107). Stella, Blanche's sister, accepts it without any question. But Blanche is different; she is candid and non-conforming to the demands that the social order has set upon women. Her ego or 'masculinity complex', whatever we name it, always prevents her from accepting any kind of discriminations between men and women. She is not ready to consider Stanley as a superior being, rather she calls him 'something- sub-human- something not quite to the stage of humanity, yet!'(Williams, 72) Blanche thinks him as 'the survivor of the Stone Age' because Stanley, representatively the manhood and a member of the old society, lacks the capability to understand the spirit and strength of new women.

At her sister's house, Blanche's masculine nature reflects many times through her behavior. She anticipates the similar freedom like Stanley. She drinks liquor, wants to dominate the people around her, likewise has expressed readiness to take on poker like Stanley and his allies. In scene three, Blanche says, 'Poker is so fascinating. Could I kibitz?'(Williams, 48), but Stanley does not allow her. Her masculinity complex is offended here many times by Stanley. Unlike Blanche, Stella is content to live in a world defined by males and their social rituals that make Blanche's new ideology appear stronger. Even verbal and physical abuse does not keep Stella away from Stanley. Blanche is shocked by Stella's attitude towards her condition that she, without any resistance, has allowed all this humiliating and sadistic behavior towards her. She believes that Stella's situation is worse than her, only she is 'not being sensible about it'. She wants to find a way for both herself and Stella out of this situation. She tells Stella; "I'm going to do something. Get hold of myself and make myself a new life!" (Williams, 73)

To Stanley, Stella is a means to assert his masculinity and his dominance; but, "Blanche is a threat in the way of asserting his masculinity" (Vaughn, 61). With the appearance of Blanche, Stanley feels a risk to lose those things that are his. She becomes a danger to his way of life; she is a powerful force, a loftier being whom he can't understand. She has never conceded to him his right to be the "king" in his own house which symbolizes the expectation of the society that women should be always as a subject under the authority of men. Blanche has drunk Stanley's liquor, eaten his food, used his house, but still has belittled him and has opposed him. It is an absolutely new experience for Stanley and of the conventional male dominated world.

Thus, when the basic man, such as Stanley, feels threatened, he must strike back. Blanche tried to break the long cherished values and norms created by so called superior male members, and Stanley, being a member of this group, can never allow that to happen. Because, according to Stanley or the male dominated world, a social life can only be peaceful with a submissive woman like Stella and authoritative male counterpart as Stanley. "Stella supports the patriarchy and is allowed to survive as Stanley's wife; Blanche is destroyed because she cannot find her identity or role in the patriarchy and is slowly forced into marginalization" (Vaughn, 93).Blanche fights to assert both her own and her sister's individuality. With the appearance of Blanche, Stanley feels a risk to lose those things that are his. She becomes a danger to his way of life. She has never conceded to him his right to be the "king" in his own house which symbolizes the expectation of the society that women should be always as a subject under the authority of men. Blanche has drunk Stanley's liquor, eaten his food, used his house, but still has belittled him and has opposed him.

It is an absolutely new experience for Stanley and of theconventional male-dominated world. Thus, when the basic man, such as Stanley, feels threatened, he must strike back. Blanche tried to break the long cherished values and norms created by so called superior male members, and Stanley, being a member of this group, can never allow that to happen. Because, according to Stanley or patriarchal culture, a social life can only be peaceful with a submissive woman like Stella and authoritative male counterpart as Stanley. Blanche is an inflexible competitor and a dangerous intruder who must be taken out.

The hypocrisy of the society regarding sexuality is revealed again in New Orleans. By rejecting Blanche and claiming that she is not the ideal woman he thought she was, Mitch draws attention to the incongruity between 
how the new women behave and what type of behavior is publicly expected from them by the society in general. Here, Williams discloses double moral standard of the American society of the late nineteenth and twentieth century that affected women. Moreover, regarding Blanche's immoral business, Stanley rebukes Stella. But when Stanley rapes Blanche has her alone in the house, nobody in the society is bothered about it. Williams says in the play; "since earliest manhood, the center of his life has been a pleasure with women, the giving and taking of it, not with weak indulgence, dependently, but with the power and pride of a richly feathered male bird among hens."(Williams, 29). It clarifies the point that, in this world, only men have the right to seek sexual pleasures as they wish.

The rape of Blanche by Stanley at the end of the play completely knocks down her as an individual and destroys her masculinity complex. The idea she bears that women are also equal to men is shattered by this incident. It also shows the contradictory principles of the society because, after the rape, no one is questioning about Stanley's purity.

This rape never torments Stanley's conscience, but it batters Blanche's mental balance. Blanche is unable to make an alliance with power. Williams makes Stanley win over Blanche which clears the idea that the culture is inviting masculinity in women by providing them a few of the exclusive opportunities of men. After that, "having no path of their own to follow, women have tended to copy men" (Thompson, 239), and this imitation of men puts women in some unwanted rivalry with men. But when these adult females hold on an active role in that contention, the society feels a threat and push them backward once more in their previous position. In the meantime of this game, some women, like Blanche, cannot tolerate the discrimination and the "traumatic experiences which keep alive the attitude of inferiority" (Thompson, 239). Accordingly, she gives up this world for Stanley since she understood this world is still too biased to allow her spirit to be spread. Stanley comes out the victor because he acts within his place in society. But because Blanche fails to conform to her rightful place in society, she is detested and even becomes ready to go to asylum because she understands that she is an alien in this world. "She is rejected even by her sister and is thrown to a place, the mental hospital, where she will not "cause disturbances" (Zak, 71). Sill this world is for Stanley, symbolically for the manhood, women are the second citizen here.

However, Blanche's mental collapse at the end of the play could be seen as defending Stanley's traditional male authority. Her fate is a critique of what most women are doomed to confront when they search for an increased control in a male-dominated society where all the power and control is in the hands of males who would do everything just to keep their power and position intact. In spite of all struggles that women undergo in such a society, they are forced into marginalization so that they would not make any troubles for the dominant power structure prevailing in the society.

Through Blanche, Williams illustrates the idea that womanhood begins with much unkindness. Women are categorized as having physical as well as intellectual inferiority from their very young age that helps men to snatch women's freedom of choice, equality with boys, and the right to be forceful. The training to be conservative, especially about their fleshly existence and self-interests, has unquestionably contributed much to a woman's weakened personality. Therefore, it will take a long time, even for the educated and self-dependent women as Blanche to get free physically and mentally from this social constructed misconception. Women still cannot attain their freedom, equality with men and, privileges until we change the whole cultural set up and create a conducive environment for all women's spontaneous psychological development from their infancy.

\section{REFERENCES}

[1] T. Williams, A streetcar named Desire (Penguin Books, New York, 1974).

[2] G, Sarah. "The New Aspect of the Woman Question." The North American Review, vol. 158, no. 448, 1894, pp. 270-276.

[3] C.M. Thompson, Cultural Pressures in the Psychology of Women, Psychiatry, Vol. 5, Iss. 3, 1942.

[4] V. Woolf, A room of one's own (Harcourt, Brace and Co, New York, 1929).

[5] Vaughn, Sally Rae, Gender Politics and Isolation in Kate Chopin's The Awakening and Tennessee Williams's A Streetcar Named Desire, Unpublished MA. Dissertation, Texas Woman's University, 2005.

[6] Zak, Deborah Jeanne, Her Story Resisting His: Madwoman in F. Scott Fitzgerald's Tender is the Night and Tennessee Williams's Glass Menagerie and A Streetcar Named Desire, Unpublished MA. Dissertation, California State University, 1996.

[7] Maiman, Nichole, Who Wants Real: I Want Magic!' Musical Madness in A Streetcar Named Desire, Unpublished MA. Dissertation, University of Maryland, 2004.

[8] Gulbicki, S. Style and Substance: Isabel Archer as a New Type of "Lady", M.A Dissertation. Seton Hall University, New Jersey, United States, 2013.

[9] Copenhaver, Bonny Ball, A Portrayal of Gender and a Description of Gender Roles in Selected American 
Modern and Postmodern Plays, Electronic Theses and Dissertations, Paper 632, 2002.

[10] Sandlin, Anita, Fear and Fascination: A Study of Thomas Hardy and the New Woman, Electronic Theses \& Dissertations. Paper 184, 2011.

[11] Estelle B. Freedman, The New Woman: Changing Views of Women in the 1920s, The Journal of American History, Vol. 61, No. 2, 1974. 